\title{
Treatment of Hazardous Solid Waste Using Solidification and Stabilization Technique
}

\author{
Yamuna Rani M. ${ }^{1}$, Bhagawan D. ${ }^{1}$, Saritha $P^{2}$, V. Himabindu ${ }^{1, *}$, V. Venkateswara Reddy ${ }^{3}$ \\ ${ }^{1}$ Centre for Environment, Institute of Science and Technology, JNTUH, Hyderabad, India \\ ${ }^{2}$ Dept. of Civil Engg. Malla Reddy College of Engineering, Hyderabad, India \\ ${ }^{3}$ Dept. of Civil Engg. JNTUHCEH, Hyderabad, India
}

Email address:

drvhimabind@jntuh.ac.in (V. Himabindu), Yamuna.m218@gmail.com (V. Himabindu)

${ }^{*}$ Corresponding author

\section{To cite this article:}

Yamuna Rani M., Bhagawan D., Saritha P., V. Himabindu, V. Venkateswara Reddy. Treatment of Hazardous Solid Waste Using Solidification and Stabilization Technique. International Journal of Mineral Processing and Extractive Metallurgy.

Vol. 6, No. 4, 2017, pp. 94-100. doi: 10.11648/j.ajep.20170604.13

Received: May 27, 2017; Accepted: June 30, 2017; Published: July 31, 2017

\begin{abstract}
The immobilization of toxic metals present in the pharmaceutical effluent treatment plant (ETP) sludge is studied using the solidification/stabilization $(\mathrm{S} / \mathrm{S})$ technique. Different mixtures of cement, lime and bentonite as binders and additives (Pulverized fuel ash (PFA), silica fume and quarry dust) are used in order to reduce the mobility of the metal constituent of the pharma sludge as well as to strengthen brick. The interaction between the S/S matrix were studied using X-ray diffraction spectroscopy (XRD), Fourier Transform Infrared Spectroscopy (FT-IR), Thermo gravimetric-Differential Thermal Analysis (TG- DTA), Unconfined Compression Strength, Toxicity characteristics leaching procedure (TCLP) tests. The results showed that the optimized composition matrix have a strong fixing capacity for heavy metal includes $\mathrm{Cu}, \mathrm{Zn}, \mathrm{Fe}, \mathrm{Co}, \mathrm{Pb}, \mathrm{Ni}$ and $\mathrm{Cd}$. All the specimens have been observed to be sufficient in achieving the target compressive strength of $0.3 \mathrm{~N} / \mathrm{mm}^{2}$ required for landfill disposal and mixed binders (Cement, Lime, and Bentonite) brick can be recommended for external use in construction i.e. for pave of pedestrian roads.
\end{abstract}

Keywords: Solidification and Stabilization, Pharmaceutical Sludge, Binder, Hazardous Waste, Brick, Compressive Strength

\section{Introduction}

Growth of population, increasing urbanization and rising standards of living due to technological innovations have contributed to an increase in the quantity of solid wastes generated by industrial, mining, domestic and agricultural activities. These wastes need to be managed properly to minimize their harmful effect on human health and environment. The development in technologies for recycling and reusing waste is critical to the success of current policies on hazardous waste management [1].

This hazardous waste might pose potential effect to human health and healthy environment due to its instability [2]. These can be potentially stabilized using solidification/ stabilization $(\mathrm{s} / \mathrm{s})$ method which not only alleviates disposal problems but also has economic, ecological and energy saving advantages [3 and 4].
Additives such as cement, clay, slogs, coal fly ash and lime are in $\mathrm{s} / \mathrm{s}$ technology to immobilize waste continents [1 and 5]. The stabilization process using cement relies on the formation of calcium silicate hydrate $\left(\mathrm{CaO} \cdot \mathrm{SiO}_{2} \cdot n \mathrm{H}_{2} \mathrm{O}\right.$, briefed as $\mathrm{C}-\mathrm{S}-\mathrm{H})$, ettringite hydrate $\left(3 \mathrm{CaO} \cdot \mathrm{Al}_{2} \mathrm{O}_{3} 3\right.$ $\left.\mathrm{CaSO}_{4} \cdot 32 \mathrm{H}_{2} \mathrm{O}\right)$ and Monosulphate $\left(3 \mathrm{CaO} \cdot \mathrm{Al}_{2} \mathrm{O}_{3} \cdot \mathrm{CaSO}_{4} \cdot 12\right.$ $\mathrm{H}_{2} \mathrm{O}$ ) in the matrix, due to the hydration reaction of portland cement. Thus, the heavy metals get chemically fixed in the lattice of hydration production as well as physically encapsulated in the matrix. In organic salts, calcium chloride is often used as accelerating additive thus guaranteeing the stabilization and solidification of the sludge [1 and 6].

Indian Pharma industry is became an essential part of modern society and waste production has been an inevitable outcome of the developmental activities [1 and 3]. In the present study the application of sludge derived from waste water pollutant coagulation (ETP sludge) from pharma 
industry into unfired bricks has been studied, which further reduces the natural resource degradation. In addition to unconfined compressive strength (UCS) measurements, leaching test, X-ray diffraction (XRD), Fourier Transform Infrared Spectroscopy (FTIR) and Thermo Gravimetric Differential Thermal Analysis (TG-DTA) have been investigated the solidification mechanism of the bricks.

\section{Materials and Method}

The materials used in this study have been given in table 1 .

Table 1. Reactant materials used for study.

\begin{tabular}{llll}
\hline S. No & Material & Purpose of use & Characteristic \\
\hline 1 & $\begin{array}{l}\text { Pharmaceutical } \\
\text { industry waste }\end{array}$ & Needed to treat & Hazardous \\
2 & Cement & Binder & $\begin{array}{l}\text { Construction } \\
\text { Compound } \\
\text { Coagulant Compound }\end{array}$ \\
3 & Lime & Binder & Hazardous \\
4 & Pulverized fuel ash & CO-Binder & Binder \\
5 & Bentonite & strength & Hazardous \\
6 & Silica Fume & $\begin{array}{l}\text { increaser } \\
\text { strength }\end{array}$ & Hazardous \\
\hline
\end{tabular}

The initial characteristic of the sludge sample has been given table 2 .

Table 2. Physico-chemical characterization of ETP sludge.

\begin{tabular}{lll}
\hline S. No & Parameter & Results \\
\hline 1 & Color & Ash Color \\
2 & State & Semi solid \\
3 & $\mathrm{pH}$ & 8.5 \\
\hline
\end{tabular}

\begin{tabular}{lll}
\hline S. No & Parameter & Results \\
\hline 4 & Moisture content $(\%)$ & $12 \%$ \\
5 & Density $\left(\mathrm{g} / \mathrm{cm}^{3}\right)$ & 0.6451 \\
6 & Specific gravity & 0.635 \\
7 & Organic matter & $14 \%$ \\
8 & $\mathrm{Zn}(\mathrm{mg} / \mathrm{Kg})$ & 131.2 \\
9 & $\mathrm{Fe}(\mathrm{mg} / \mathrm{Kg})$ & 2012.1 \\
10 & $\mathrm{Ni}(\mathrm{mg} / \mathrm{Kg})$ & 80.8 \\
11 & $\mathrm{Co}(\mathrm{mg} / \mathrm{Kg})$ & 12.7 \\
12 & $\mathrm{~Pb}(\mathrm{mg} / \mathrm{Kg})$ & 37.7 \\
13 & $\mathrm{Cd}(\mathrm{mg} / \mathrm{Kg})$ & 3 \\
14 & $\mathrm{Cu}(\mathrm{mg} / \mathrm{Kg})$ & 282.7 \\
\hline
\end{tabular}

\subsection{Methodology}

The unfired bricks have been prepared in duplicates using 3 binders (cement, lime and bentonite). The ETP sludge has been dried in a hot air oven for $24 \mathrm{~h}$ at $105^{\circ} \mathrm{C}$ and ground to less than $9.5 \mathrm{~mm}$ in size to aid workability of the sludge-ashbinder mixture during casting. The PFA and binder are mixed in a small container, after 5 min it is blended with water. The dried sludge is added to blended mixer. After fine mix, the industrial by-products silica fume and quarry dust are added to develop the strength of the brick.

This unfired bricks from waste are fabricated in wooden moulds with internal dimensions of $120 \mathrm{~mm} \mathrm{X} 65 \mathrm{~mm}$ X 30 $\mathrm{mm}$. The moulds are filled with above prepared admixes and kept in moist condition for $24 \mathrm{~h}$. At the end of this period the bricks are removed from the moulds and cured in air at room temperature for 28 days. The structural, functional groups, thermal behaviour, heavy metal leachability and strength of the $\mathrm{s} / \mathrm{s}$ matrixes have been carried to evaluate the workability of $\mathrm{s} / \mathrm{s}$ process. The composition of the bricketing materials are reported in table 3.

Table 3. Composition of S/S Matrixes.

\begin{tabular}{|c|c|c|c|c|c|c|c|}
\hline \multirow{3}{*}{ COMPOUNDS } & \multicolumn{7}{|c|}{ COMPOSITION } \\
\hline & \multicolumn{3}{|c|}{ SERIES A } & \multicolumn{3}{|c|}{ SERIES B } & \multirow{2}{*}{ SERIES C } \\
\hline & TYPE I & TYPE II & TYPE III & TYPE I & TYPE II & TYPE III & \\
\hline Nomenclature of The Bricks & $\mathrm{AC} 1$ & $\mathrm{AB} 1$ & $\mathrm{AC} 1$ & BLB 1 & BBC 1 & BLC 1 & CLBC 1 \\
\hline SLUDGE $(\%)$ & 10 & 10 & 10 & 10 & 10 & 10 & 10 \\
\hline PULVERISED FUEL ASH (\%) & 35 & 35 & 35 & 35 & 35 & 35 & 30 \\
\hline LIME $(\%)$ & 30 & - & - & 15 & - & 15 & 10 \\
\hline BENTONITE (\%) & - & 30 & - & 15 & 15 & - & 10 \\
\hline SILICA FUME (\%) & 20 & 20 & 20 & 20 & 20 & 20 & 20 \\
\hline QUARRY DUST (\%) & 5 & 5 & 5 & 5 & 5 & 5 & 10 \\
\hline TOTAL $(\%)$ & 100 & 100 & 100 & 100 & 100 & 100 & 100 \\
\hline
\end{tabular}

\subsection{Analytical Techniques}

\subsubsection{X-ray Diffraction (XRD)}

The crystalline structure of the brick, which affords better understanding on the reaction products, is analyzed by X-ray diffraction (XRD). XRD scans of brick material is performed with Bruker D 8 advanced X-ray diffractometer operated at $40 \mathrm{kV}$ and $30 \mathrm{~mA}(\mathrm{CuK}-a)$ pha radiation $\left.\left(\lambda=1.5418 \mathrm{~A}^{\circ}\right)\right)$ in the range $20-80^{\circ} 2 \theta$ at scanning rate of $1^{\circ} 2 \theta$ per minute.

\subsubsection{Fourier Transform Infrared Spectroscopy (FTIR)}

Infrared spectra analysis is made using Perkin Elmer FTIR spectrometer [7, 8] using $\mathrm{KBr}$ method. Wave length number ranges from $4000-400 \mathrm{~cm}^{-1}$. Pellet making has been done using hydraulic pump manufactured by Kimaya Engineers.

\subsubsection{Thermo Gravimetric Differential Thermal Analysis (TG-DTA)}

The thermal behavior and weight loss of the sample is determined using TG-DTA. TG-DTA of the sample has been done by S-II EXSTAR-6000, TG/DTA-6300 thermal analyzer. Sample loaded in aluminum container and heated to $800^{\circ} \mathrm{C}$ at the rate of $2 \mathrm{~K} / \mathrm{min}$ with air circulating at a speed of $150 \mathrm{ml} / \mathrm{min}$. 


\subsubsection{Toxicity Characteristic Leaching Procedure (TCLP)}

Toxicity Characteristic Leaching Procedure (TCLP) of S/S sludge bricks (waste create bricks) has been conducted as per the standard procedures described by USEPA 1996 (8). The heavy metals are analyzed by Atomic Absorption Spectrometer (AAS).

\subsubsection{Unconfined Compression Strength (UCS)}

UCS of unfired cubes are measured by compression testing machine as per BIS specification code (IS 4031) (IS: 10771992).

\section{Results and Discussion}

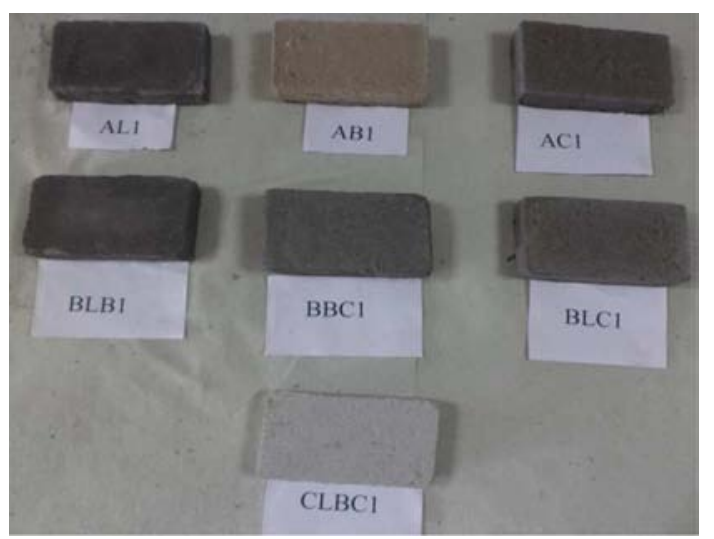

Figure 1. Bricks Prepared by solidification and stabilization of wastes.

Where AL 1 - lime binder brick; AB 1- bentonite binder brick; AC 1- cement binder brick; BLB 1- bentonite and lime mixed binder brick; BBC 1- bentonite and cement mixed binder brick; BLC 1- lime and cement mixed binder brick; CLBC 1- cement, lime and bentonite mixed binder brick.

The fig 1 shows the s/s matrixes, prepared using pharma ETP slude with different binders and additives. The detailed results and discussion are presented as follows.

\subsection{Reaction Product Identification by XRD in the Brick Matrix}

X-ray diffraction (XRD) pattern showed the crystalline structure of the brick, which affords better understanding on the reaction products. $\mathrm{AL} 1, \mathrm{AB} 1, \mathrm{AC} 1, \mathrm{BLB} 1, \mathrm{BBC} 1$, BLC 1 and CLBC 1 bricks diffractograms have been observed to shown similar compounds like portlandite, gypsum, ettringite, alite, belite, quartz and calcite peaks (fig2 ). Only the ettringite peak has not observed in AB 1. The intensities of gypsum reflection peaks have stronger intense than that of portlandite in AL 1, AB 1, AC 1, BLB 1, BBC 1 bricks, while compared to BLC 1 and CLBC 1 bricks.

In CLBC 1 matrix it has been observed that the intensity of calcite is weaker than ettringite reflection peak.

Portlandite resulted from cement hydration which can react with silica in the sludge to form $\mathrm{C}-\mathrm{S}-\mathrm{H}$ gel (pozzolanic reactions). This can be further elucidated by the following equations:

$$
\begin{gathered}
2\left(3 \mathrm{CaO} \cdot \mathrm{SiO}_{2}\right)+6 \mathrm{H}_{2} \mathrm{O} \rightarrow 3 \mathrm{CaO} \cdot 2 \mathrm{SiO}_{2} \cdot 3 \mathrm{H}_{2} \mathrm{O}\left(3 \mathrm{Ca}(\mathrm{OH})_{2}\right) \\
2\left(2 \mathrm{CaO} \cdot \mathrm{SiO}_{2}\right)+4 \mathrm{H}_{2} \mathrm{O} \rightarrow 3 \mathrm{CaO} \cdot 2 \mathrm{SiO}_{2} \cdot 3 \mathrm{H}_{2} \mathrm{O}\left(\mathrm{Ca}(\mathrm{OH})_{2}\right) \\
3 \mathrm{Ca}(\mathrm{OH})_{2}+2 \mathrm{SiO}_{2} \rightarrow 3 \mathrm{CaO} \cdot 2 \mathrm{SiO}_{2} \cdot 3 \mathrm{H}_{2} \mathrm{O}
\end{gathered}
$$

Tricalcium and Dicalcium silicates in portland cement reacted concurrently with water and produced strength enhancing compounds calcium hydroxide (portlandite) and ettringite (E).

Ettringite has been formed via the reaction of calcium and alumina in lime or cement with sulphate present in sludge, it favoured the compressive strength. The presence of calcite is attributed by the carbonation of sample during drying and preparations [9].
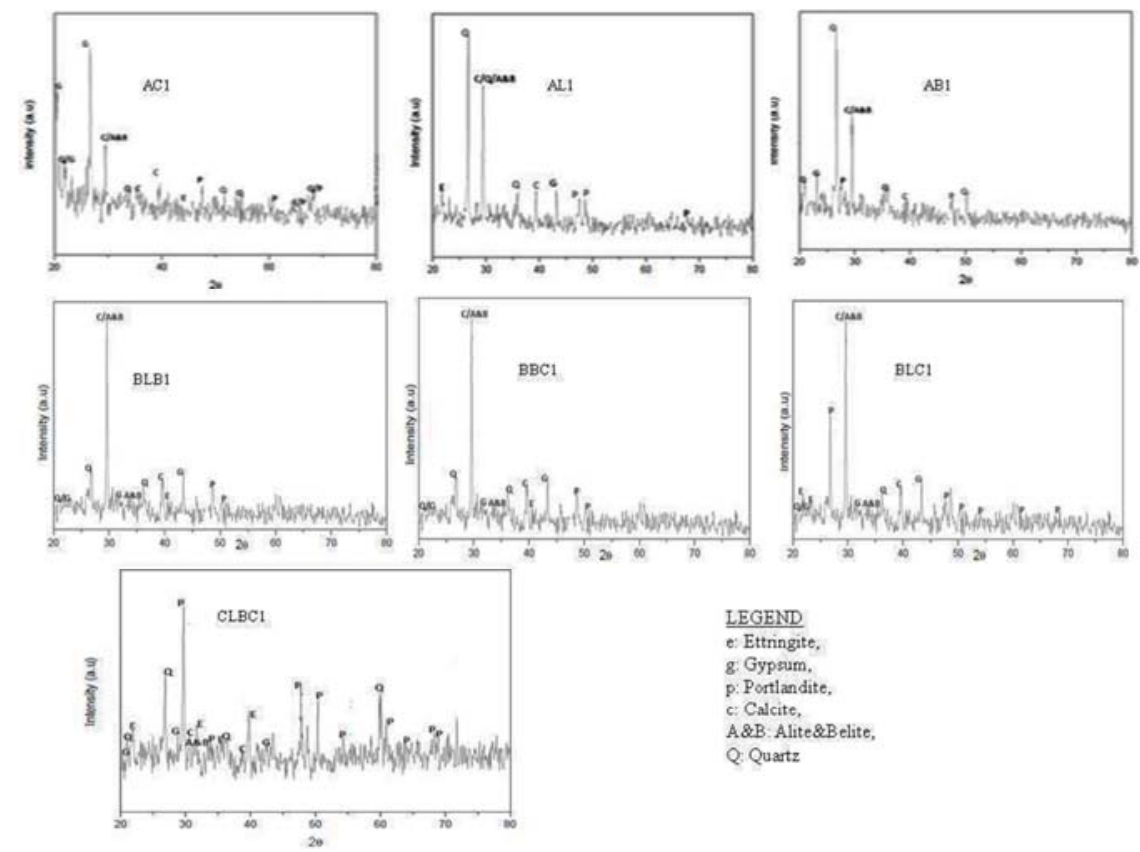

LEGEND

e: Ettringite,

g: Gypsum,

p. Portlandite.

A\&B Alite\&Belite,

Q: Quartz

Figure 2. XRD pattern of the brick matrix. 


\subsection{Functional Groups Analysis by FT-IR}

FTIR analysis of the dried unfired bricks has been carried in the frequency ranged between 400 and $4000 \mathrm{~cm}^{-1}$. The IR spectra results of AC 1, AL 1, AB 1, BLC 1, BLB 1, BBC 1 and CLBC 1 geo-polymer matrixes had shown in fig-3. The considerable broad bands located at $3200-1700 \mathrm{~cm}^{-1}$ are assigned to $\mathrm{O}-\mathrm{H}$ stretching and $\mathrm{H}-\mathrm{O}-\mathrm{H}$ bending respectively [10]. The intense peaks at about 875.57 and $712 \mathrm{~cm}^{-1}$ are attributed to the metal species with $\mathrm{O}-\mathrm{H}$ bonding in all the unfired brick samples. $\mathrm{O}-\mathrm{H}$ stretching band centered at $3424.35 \mathrm{~cm}^{-1}, 3435 \mathrm{~cm}^{-1}, 3417 \mathrm{~cm}^{-1}$ corresponding to the bound water molecules in the AL 1, AB 1 and BLB 1 bricks. A strong band around $1402 \mathrm{~cm}^{-1}-1428 \mathrm{~cm}^{-1}$ is assigned to calcite present in the Bi-binder bricks (BBC 1, BLB 1 and BLC 1) matrix. Ettringite has been observed around $1106 \mathrm{~cm}^{-1}$ in all unfired brick matrixes. Except $\mathrm{AB} 1$ and $\mathrm{AC} 1$ matrix, the presence of strong peaks at 874.57 and $783.41 \mathrm{~cm}^{-1}$ clearly confirm that the metal contaminants have been effectively stabilized within the ettringite bonds [4 and 11]. Around 1430 $\mathrm{cm}^{-1}, \mathrm{CH}_{3}$ bending has been observed in $\mathrm{AB} 1, \mathrm{AL} 1, \mathrm{BBC} 1$ and CLBC 1 matrixes [12]. Abroad envelope centered at 3440 $\mathrm{cm}^{-1}$ has been assigned to $-\mathrm{OH}$ stretch of calcium hydroxide in AC 1, BLC 1 and CLBC 1 [13]. Portilandate/Calcite is represented at $1435.62 \mathrm{~cm}^{-1}$ in CLBC 1 matrix.
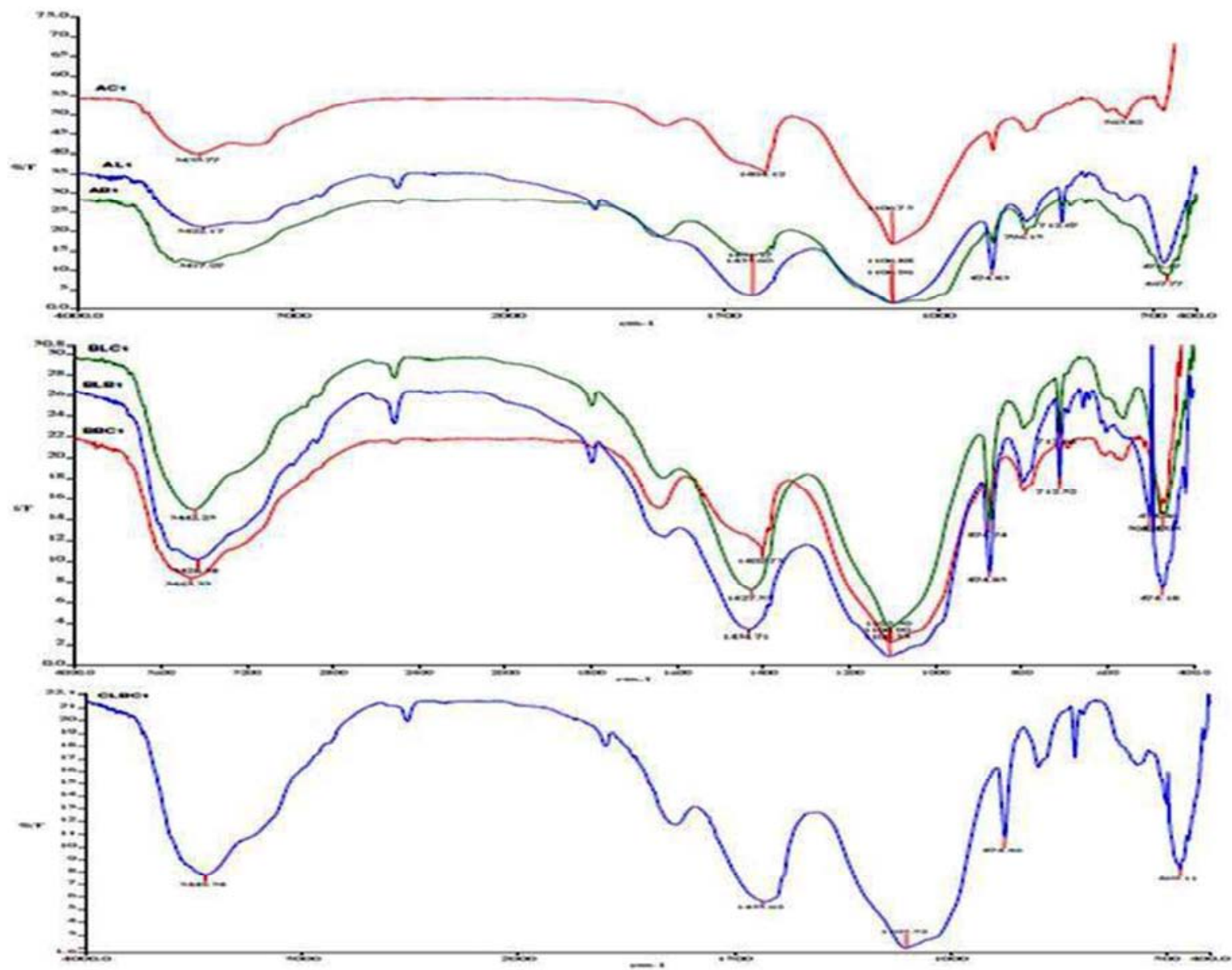

Figure 3. FTIR analysis of the bricks.

\subsection{Thermo Gravimetric-Differential Thermal Analysis (TG- DTA)}

In thermo gravimetric analysis all the brick samples have been shown weight loss, where the identifiable 3 zones have been observed. The first zone of the mass loss might be attributed to the evaporation of physically and chemically bounded water, second zone of the mass loss is due to the decomposition of the stable hydrates of the calcium aluminates and calcium silicates. Finally the $3^{\text {rd }}$ zone of the mass loss represents the decomposition of the calcium carbonates at $780^{\circ} \mathrm{C}$ [14]. The Portland dehydration is represented at $470^{\circ} \mathrm{C}-510^{\circ} \mathrm{C}[15$ and 16]. Based on the thermal analysis weight loss of the unfired bricks are in the following order: AC $1>$ BLB $1>$ BLC $1>$ BBC $1>$ CLBC $1>$ AL $1>$ AB 1.

Endothermic peak at $110^{\circ} \mathrm{C}$ has been observed for $\mathrm{AC} 1$, $\mathrm{AB} 1, \mathrm{BLB} 1$ and BLC 1 brick specimens, while the exothermic peak at $500^{\circ} \mathrm{C}$ has been observed in all the brick matrixes. The endothermic peak around $110^{\circ} \mathrm{C}$ corresponds to removal of structural water from matrixes [1]. However the exothermic peak at $500^{\circ} \mathrm{C}$ correspond to dehydroxylation of the portland compounds $[1,6,16,25]$.

In $\mathrm{AB} 1, \mathrm{BLB} 1, \mathrm{BLC} 1$ and CLBC 1 bricks the exothermal peaks have been observed between $750^{\circ} \mathrm{C}$ - 
$810^{\circ} \mathrm{C}$, which is corresponds to the decomposition of calcite and alite $[6,17]$.

In CLBC 1 brick, endothermic peak hasn't observed. Such
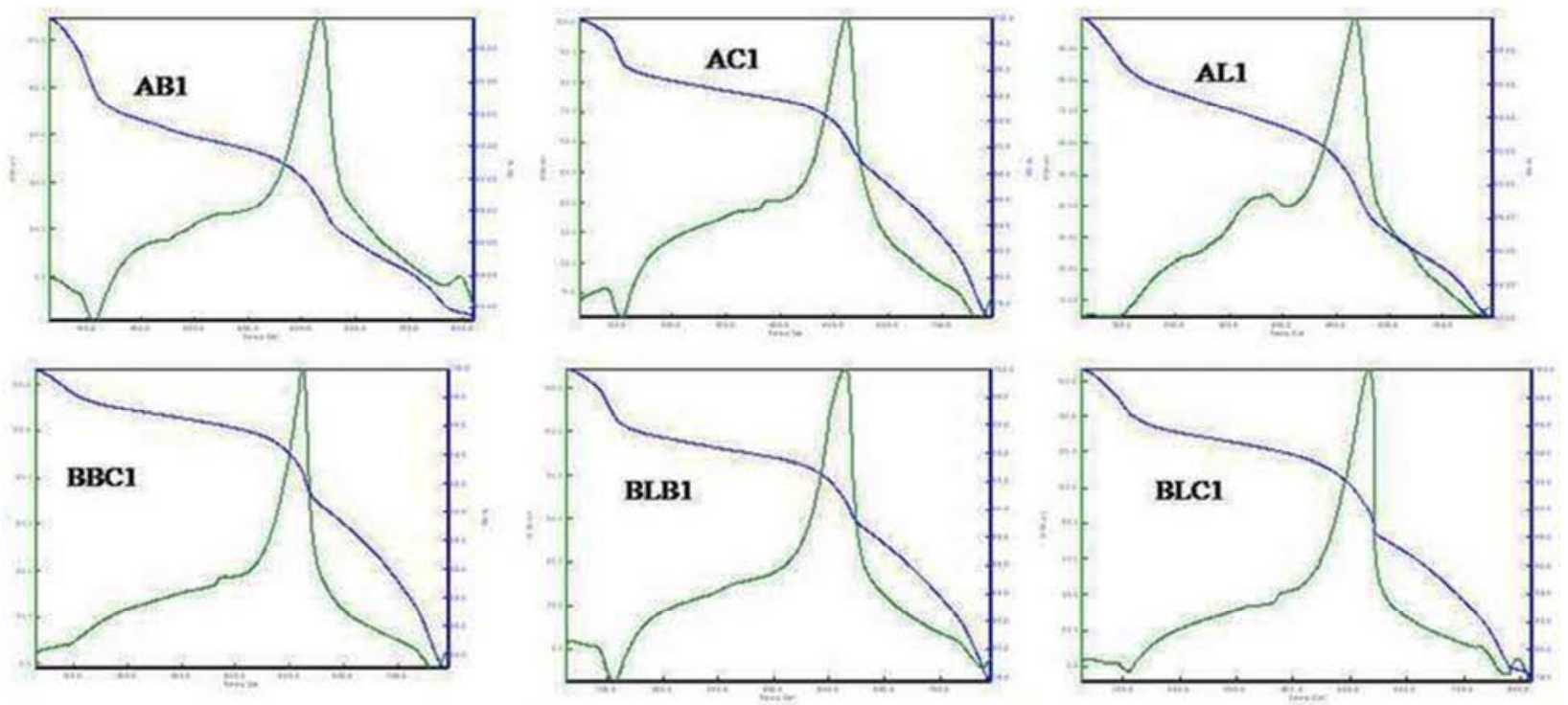

type of bricks might be usable for heat managing application (furnace) practices, since they do not have heat loss.

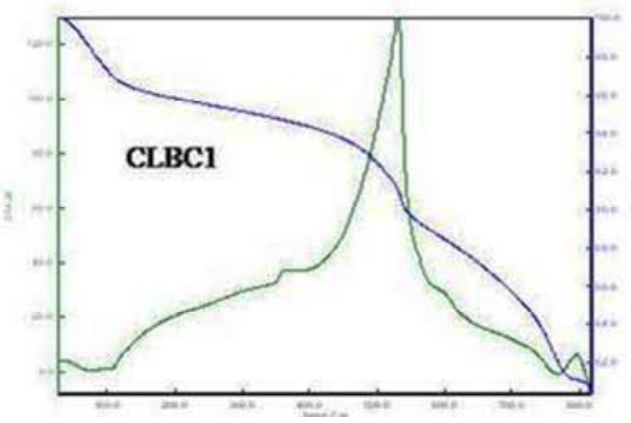

Figure 4. TG DTA analysis of the samples.

\subsection{TCLP Leaching Studies}

Metal Leaching test has been conducted to investigate the immobilizing ability of S/S formulations [18 and 19]. The variable metal concentrations in the leachate of the different unfired bricks (s/s) have been reported in Table-4. Results from TCLP method shown insignificant levels of heavy metals and comply with the concentration limits set by EPA (2005) [20].

The metals concentrations in the leachate have been observed to be within the acceptable limits. It has been observed that fly ash along with lime, bentonite and cement are very effective in lowering the leaching of heavy metals. Lime, bentonite and cement maintain the sludge at a high $\mathrm{pH}$ in the range of 9-11, immobilizing the toxic heavy metals as insoluble hydroxides [19 and 21]. The hydrated cementatious products bind the metals either through chemical or physical bonds. The addition of fly ash with pozzalon material is very effective in lowering the leaching of heavy metals in waste [17, 19 and 21].

The complexes in the sludge might react with the silicate matrix $(\mathrm{C}-\mathrm{S}-\mathrm{H})$ and $\mathrm{C}-\mathrm{A}-\mathrm{H}$ as long as silicate and aluminates are free available. Chemical gypsum in the sludge reacted with alumina phases to form ettringite, which contributed to compressive strength as well as restricts the release of the heavy metals from unfired bricks [17, 19]. Under aqueous condition $\mathrm{OH}$ ions are released from calcium hydroxide and other forms of hydroxyl compounds present in the bricks contributes alkaline environment, which reduced the release of heavy metals.

Table 4. Concentration of Heavy Metals in Leachate (TCLP).

\begin{tabular}{llllllll}
\hline \multicolumn{7}{l}{ Concentration Level (mg/L) } \\
\hline Bricks & Cu & Zn & Fe & Co & Pb & Ni & Cd \\
\hline AL 1 & $<0.1$ & $<0.1$ & $<0.1$ & $<0.1$ & $<0.1$ & $<0.1$ & $<0.1$ \\
AB 1 & $<0.1$ & $<0.1$ & $<0.1$ & $<0.1$ & $<0.1$ & $<0.1$ & $<0.1$ \\
AC 1 & $<0.1$ & $<0.1$ & $<0.1$ & $<0.1$ & $<0.1$ & $<0.1$ & $<0.1$ \\
BLB 1 & $<0.1$ & $<0.1$ & $<0.1$ & $<0.1$ & $<0.1$ & $<0.1$ & $<0.1$ \\
BBC 1 & $<0.1$ & $<0.1$ & $<0.1$ & $<0.1$ & $<0.1$ & $<0.1$ & $<0.1$ \\
BLC 1 & $<0.1$ & $<0.1$ & $<0.1$ & $<0.1$ & $<0.1$ & $<0.1$ & $<0.1$ \\
CLBC 1 & $<0.1$ & $<0.1$ & $<0.1$ & $<0.1$ & $<0.1$ & $<0.1$ & $<0.1$ \\
\hline
\end{tabular}

\subsection{Evaluation of Physical Engineering Property of the $S / S$ Samples by Compressive Strength}

Unconfined compressive strength (UCS) is one of the important parameter, which evaluates the cohesive solidified effect of mixer (waste). After 28 days of the drying [22], the compressive strengths of the solidified sludge bricks are 
measured and represented in fig-5. According to the compressive strength analysis the specimens have been observed to be sufficient to achieve the target compressive strength of $0.3 \mathrm{~N} / \mathrm{mm}^{2}$ required for land fill disposal [6].

The compressive strength of the single binder bricks i.e., $\mathrm{AL} 1, \mathrm{AB} 1$ and $\mathrm{AC} 1$ are ranged from $0.30 \mathrm{~N} / \mathrm{mm}^{2}-4.96$ $\mathrm{N} / \mathrm{mm}^{2}$ and $2.65 \mathrm{~N} / \mathrm{mm}^{2}-5.45 \mathrm{~N} / \mathrm{mm}^{2}$ for double bindersludge bricks i.e., BLB 1, BBC 1, BLC 1 and CLBC 1, where as the compressive strength of CLBC 1 brick is higher than that all other bricks (single and double binder).

All the brick specimens except bentonite binder [Reason for failure of bricks with Bentonite as binder has to be explained as bonding due to slag reaction take at elevated temperatures in case of Bentonite] bricks are observed to have the minimum brick compressive strength of $3.5 \mathrm{~N} / \mathrm{mm}^{2}$ as per the Bureau of Standards (IS: 12894-2002). The AL 1, AC 1, BLC 1 and CLBC 1 bricks met the damp-proof course2 class brick strength [23, 24] according to (BS 3921:1985).

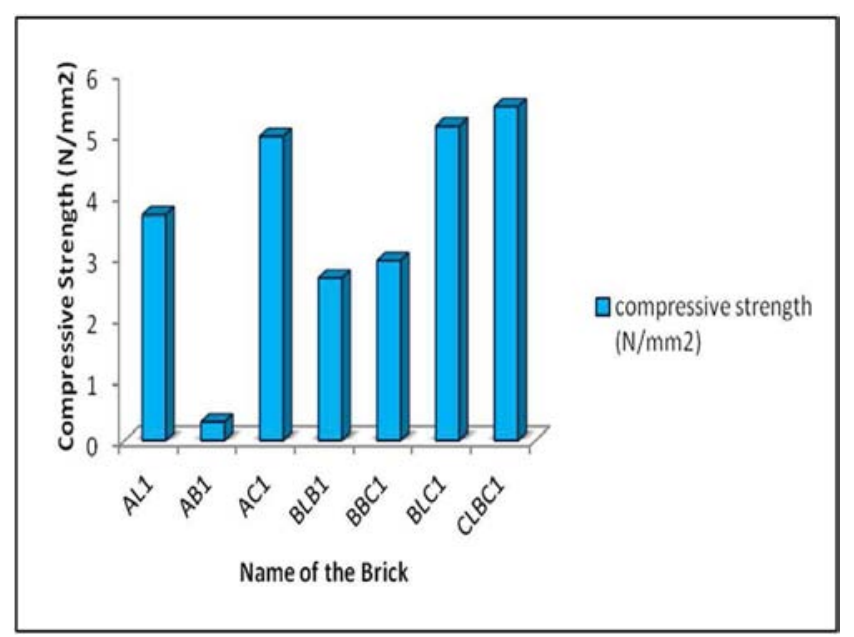

Figure 5. Compressive strength of bricks after 28 days.

\section{Conclusion}

(1) Hardening time of the bricks was observed to be 2 days.

(2) The risk level of toxic metals leaching $(\mathrm{Pb}, \mathrm{Zn}, \mathrm{Ni}$, $\mathrm{Cu}, \mathrm{Ni}, \mathrm{Co}, \mathrm{Cd}$, and $\mathrm{Fe}$ ) from the waste materials, after the treatment $(\mathrm{S} / \mathrm{S})$ is within the acceptable levels. Therefore the sludge from pharma ETP having a potential to reuse as construction materials for different applications.

(3) The results of the study showed that the S/S method effectively acceptable for treatment of the hazardous solid waste of the pharmaceutical ETP sludge combined with non-hazardous material (PFA, SF and QD).

(4) Bentonite alone has been observed to be not suitable as binder in $\mathrm{S} / \mathrm{S}$ treatment.

(5) Mixed binders (Cement, Lime, and Bentonite) brick can be recommended for external use in construction i.e. for pave of pedestrian roads. As well as it can be used for furnace constructions.
(6) This study concludes that the construction raw materials can be replaced with industrial waste byproducts in some extended compositions.

\section{References}

[1] Selnur Ucaroglu, Ilhan Talinli, Recovery and safer disposal of phosphate coating sludge by solidification/stabilization, Journal of Environmental Management. 105: (2012) 131-137.

[2] Andres A, Ibanez R., Ortiz I, Irabien J. A, Experimental study of the waste binder anhydrite in the solidification/ stabilization process of heavy metals. Journal of hazardous materials 57: (1998) 155-168.

[3] Zhenhong Liu, Quanyuan Chen, Utilization of the sludge derived from dyestuff-making wastewater coagulation for unfired bricks. Construction and Building Materials 25: (2011) 1699-1706.

[4] Safiuddin Md, Mohd Zamin Jumaat, Salam M. A, Islam M. S, Hashim $R$ Utilization of solid wastes in construction materials. International Journal of the Physical Sciences 5: (2010) 19521963.

[5] Vander sloot H. A, Comparison of the characteristic leaching behavior of cements using standard (EN 196-1) cement mortar and an assessment of their long-term environmental behavior in construction products during service life and recycling. Cem. Concr. Res. 30: (2000) 1079-1096.

[6] Guangren $Q$, Yali C, Pengcheong C, Joohwa T, Utilization of MSWI fly ash for stabilization/solidification of industrial waste sludge. Journal of Hazardous Materials B 129: (2006) 274-281.

[7] Ilangovana $R$, Mahendrana $N$, Nagamanib $K$ Strength and Durability Properties of Concrete Containing Quarry Rock Dust as Fine Aggregate. ARPN J. Eng. Appl. Sci. 3: (2008) 20-26.

[8] Langan B. W, Weng K, Ward M. A, Effect of silica fume and fly ash on heat of hydration of Portland cement. Cement and Concrete Research 32: (2002) 1045-1051.

[9] Zhenhong L, Quanyuan C, Utilization of the sludge derived from dyestuff-making wastewater coagulation for unfired bricks. Construction and Building Materials 25: (2011) 16991706.

[10] Kornkanok B, Vanchai S, Kedsarin P, Prinya C, Improved geopolymerization of bottom ash by incorporating fly ash and using waste gypsum as additive. Cement and Concrete Composites 34: (2012) 819-824.

[11] Swarnalatha S, Srinivasulu T, Srimurali M, Sekaran G Safe disposal of toxic chrome buffing dust generated from leather industries. Journal of Hazardous Materials 150: (2008) 290 299.

[12] Sarkar A, Ruma $R$, Udaybhanu $G$, Basu A. K, A Comprehensive Characterization of Fly Ash from a Thermal Power Plant in Eastern India. Fuel Processing Technology 87: (2006) 259-277.

[13] Swarnalatha S, Ramani K, Geetha Karthi A, Sekaran G, Starved air combustion-solidification/stabilization of primary chemical sludge from a tannery. Journal of Hazardous Materials 137: (2006) 304-13. 
[14] Nurdeen M. Altwair, Megat Azmi, Megat Johati, Syed Fuad Saiyid, Strength Activity Index and Micro Structural Characteristics of Treated Palm Oil Fuel Ash. International Journal of Civil \& Environmental Engineering 11: (2011) 100107.

[15] Zhenhong L, Quanyuan C, Utilization of the sludge derived from dyestuff-making wastewater coagulation for unfired bricks. Construction and Building Materials 25: (2011) 16991706.

[16] Tantawy M. A, Ei-Roudi, A. M, Elham M. Abdalla, Abdelzaher, $M$. $A$, Evaluation of the pozzolanic activity of sewage sludge ash. International scholarly research network. Article ID 487037: (2012) Doi:10.5402/2012/487037.

[17] Eisa E. Hekal, Wafaa S. Hegazi, Essam A. Kishar, Maha R. Mohamed Solidification/stabilization of Ni (II) by various cement pastes, Construction and Building Materials 25: (2001) 109-114.

[18] Aeslina Abdul Kadir, Abbas Mohajerani, Felicity Roddick, John Buckeridge, Density, Strength, Thermal Conductivity and Leachate Characteristics of Light-Weight Fired Clay Bricks Incorporating Cigarette Butts. International Journal of Civil and Environmental Engineering 2: (2010) 179-184

[19] Albinas gailius, Bozena vacenovska, Rostislav drochytka,
Hazardous Wastes Recycling by Solidification/Stabilization Method. Materials science 16: (2010) 165-169.

[20] EPA. Records of decision analysis of superfund sites employing solidification / stabilization as component of the selected remedy. Washington, DC: USEPA, 1994.

[21] Minocha, A. K, Neeraj Jain, Verma, C. L, Effect of organic materials on the solidification of heavy metal sludge. Construction and Building materials 17: (2003) 1-5.

[22] American Concrete Institute (ACI) Committee 201, Guide to Durable Concrete. American Concrete Institute, Farmington Hills, Michigan, 1992, pp.1-41.

[23] Tabin Rushad, S, Abhishek Kumar, Duggal, S. K, Mehta, P. K, Experimental Studies on Lime-Soil-Fly Ash Bricks. International Journal of Civil and Structural Engineering 1: (2011) 994-1002.

[24] Alireza Naji Givi, Suraya Abdul Rashid, Farah Nora A. Aziz, Mohamad Amran Mohd Salleh, Contribution of Rice Husk Ash to the Properties of Mortar and Concrete: A Review. Journal of American Science 6: (2010) 157-165.

[25] Sha W, O Neill E. A, Guo Z, Differential scanning calorimetry study of ordinary Portland cement. Cement and Concrete Research 29, (1999) 1487-1489. 